\title{
Estimating soybean crop areas using spectral-temporal surfaces derived from MODIS images in Mato Grosso, Brazil
}

\author{
Rui Dalla Valle Epiphanio(1), Antonio Roberto Formaggio(2), Bernardo Friedrich Theodor Rudorff(2), \\ Eduardo Eiji Maeda ${ }^{(3)}$ and Alfredo José Barreto Luiz ${ }^{(4)}$
}

\begin{abstract}
(1)Louis Dreyfus Commodities Brasil S.A., Avenida Brigadeiro Faria Lima, no 1.355, 13o andar, CEP 01452-919 São Paulo, SP, Brazil. E-mail: rui.epiphanio@Idcommodities.com (2)Instituto Nacional de Pesquisas Espaciais, Caixa Postal 515, CEP 12245-970 São José dos Campos, SP, Brazil. E-mail: formag@dsr.inpe.br, bernardo@dsr.inpe.br ${ }^{(3)}$ University of Helsinki, Department of Geosciences and Geography, Gustaf Hällströmin katu 2, Kumpula, Fl-00014, Helsinki, Finland. E-mail: eduardo.maeda@helsinki.fi ${ }^{(4)}$ Embrapa Meio Ambiente, Caixa Postal 69, CEP 13820-000 Jaguariúna, SP, Brazil. E-mail: alfredo@cnpma.embrapa.br
\end{abstract}

Abstract - The objective of this work was to evaluate the application of the spectral-temporal response surface (STRS) classification method on Moderate Resolution Imaging Spectroradiometer (MODIS, $250 \mathrm{~m}$ ) sensor images in order to estimate soybean areas in Mato Grosso state, Brazil. The classification was carried out using the maximum likelihood algorithm (MLA) adapted to the STRS method. Thirty segments of 30x30 km were chosen along the main agricultural regions of Mato Grosso state, using data from the summer season of 2005/2006 (from October to March), and were mapped based on fieldwork data, TM/Landsat-5 and CCD/ CBERS-2 images. Five thematic classes were considered: Soybean, Forest, Cerrado, Pasture and Bare Soil. The classification by the STRS method was done over an area intersected with a subset of 30x30-km segments. In regions with soybean predominance, STRS classification overestimated in $21.31 \%$ of the reference values. In regions where soybean fields were less prevalent, the classifier overestimated $132.37 \%$ in the acreage of the reference. The overall classification accuracy was $80 \%$. MODIS sensor images and the STRS algorithm showed to be promising for the classification of soybean areas in regions with the predominance of large farms. However, the results for fragmented areas and smaller farms were less efficient, overestimating soybean areas.

Index terms: Glycine max, accuracy, agricultural statistics, classification, remote sensing, thematic map.

\section{Estimativa de áreas de soja usando superfícies espectro-temporais derivadas de imagens MODIS em Mato Grosso, Brasil}

Resumo - O objetivo deste trabalho foi avaliar a aplicação do método de classificação por superfícies de resposta espectro-temporal (STRS) em imagens do sensor Moderate Resolution Imaging Spectroradiometer (MODIS, $250 \mathrm{~m}$ ) para estimar áreas de plantio de soja no Estado de Mato Grosso, Brasil. A classificação foi realizada usando o algoritmo de máxima verossimilhança (MLA) adaptado ao algoritmo STRS. Trinta segmentos de $30 \times 30 \mathrm{~km}$ foram escolhidos ao longo das principais regiões agrícolas do estado, com dados da safra de verão de 2005/2006 (outubro a março), e mapeados com base em dados de campo e de imagens orbitais TM/Landsat-5 e CCD/CBERS-2. Cinco classes temáticas foram consideradas: Soja, Floresta, Cerrado, Pastagem e Solos Expostos. A classificação pelo método das STRS foi feita com base em uma área interseccionada por um subconjunto de segmentos de $30 \times 30 \mathrm{~km}$. O STRS superestimou os valores de referência em $21,31 \%$ em regiões com predomínio da cultura da soja e em $132,37 \%$ em regiões nas quais a soja era menos predominante. A exatidão global da classificação foi de 80\%. As imagens MODIS e o algoritmo STRS mostraram-se promissores para a classificação da soja em regiões com predominância de grandes fazendas. Entretanto, os resultados para áreas fragmentadas em fazendas menores foram menos eficientes, superestimando as áreas de soja.

Termos para indexação: Glycine max, acurácia, estatísticas agrícolas, classificação, sensoriamento remoto, mapa temático.

\section{Introduction}

The availability of reliable information of the agricultural production is increasingly a fundamental demand in the decision making process, both in national and international scenarios (Pino, 1999; Epiphanio et al., 2002; Dronin \& Bellinger, 2005; Epiphanio, 2007; Castillejo-González et al., 2009). One of the main variables involved in the assessment of agricultural production is the sowed or planted acreage 
of important crops. The operational methodology currently applied to perform crop forecasting in Brazil is made with extensive, prolonged, expensive and subjective surveys based on the opinion of technical agents involved in the agricultural segment (Instituto Brasileiro de Geografia e Estatística, 2002); thus, the analysis of the errors and uncertainties involved in this methodology is not practicable. Therefore, an increasing demand is observed for crop forecasts derived from remote sensing data, which allow faster results, with higher accuracy and lower costs than the traditional techniques (Food and Agriculture Organization of the United Nations, 1998; Prasad, 2006).

Previous works, carried out with the TM-Landsat and the CCD-CBERS sensors, with a spatial resolution of approximately 30 and $20 \mathrm{~m}$ respectively, showed that these sensors are appropriate for the quantification of crop areas from the point of view of its spatial resolution (Chen, 1990; Sanches, 2004; Soares et al., 2008). However, the temporal resolution of such satellites, which ranges around 16 days or more, is still a problem in the operational use of this kind of data for crop forecasting, given the high probability of cloud cover along the summer season (Ippoliti-Ramilo, 1999), especially in non-irrigated crops at tropical regions. In this context, the MODIS sensor, launched in 1999 and 2002 on board of the Terra and Aqua satellites respectively, represents a great opportunity for monitoring medium and large agricultural properties (Doraiswamy et al., 2004), offering almost daily images, increasing the probability of cloud free data, with a spatial resolution of up to $250 \mathrm{~m}$ (Justice et al., 2002).

Mapping of crop areas must take into account the high dynamics of the agricultural activities, and it is indicated that techniques using the spectral-temporal profiles of the crops should be considered (Badhwar et al., 1982). Among the multi-spectral-temporal analyses, the classification using the spectral-temporal response surface (STRS), developed by Vieira (2000), can be highlighted. A STRS is a model that describes the pixel pattern of multispectral images acquired in different dates. Instead of using reflectance values, this methodology uses parameterized polynomial coefficients of each STRS, for each pixel of a spectral-temporal data series. Each pixel is represented in a tridimensional space with control points spatially distributed in the spectral, temporal and reflectance components disposed in the $\mathrm{X}, \mathrm{Y}$ and $\mathrm{Z}$ axes respectively, and each class of the studied area has a specific STRS (Vieira et al., 2002).

The objective of the present work was to evaluate the application of the STRS method on MODIS images in order to identify soybean areas in Mato Grosso state, Brazil.

\section{Material and Methods}

The study area is located in the Mato Grosso state $\left(6^{\circ} 00^{\prime} \mathrm{S}\right.$ to $19^{\circ} 45^{\prime} \mathrm{S}$ and $50^{\circ} 06^{\prime} \mathrm{W}$ to $\left.62^{\circ} 44^{\prime} \mathrm{W}\right)$, in the Brazilian central region.

The following orbital data were used: 1 , ten scenes of Thematic Mapper (TM) sensor onboard satellite Landsat-5, acquired between October $1^{\text {st }}, 2005$ and March 31, 2006 (crop year 2005/2006), from Landsat World Reference System's (WRS) orbits/points 224/70, 224/71, 224/72, 225/70, 225/72, 227/68, 227/69, $227 / 70,228 / 69,228 / 70 ; 2$, scenes of charge coupled device (CCD) camera onboard satellite CBERS-2, acquired in the same TM/Landsat data time period; and 3, MOD13Q1 product (Justice et al., 2002), which provides enhanced vegetation index (EVI) of 16-day composite images from the Terra/MODIS sensor (acquired in the same time period as TM/Landsat), tile H12V10, which encompass nearly $90 \%$ of the Mato Grosso state territory and practically its entire agricultural area.

The pre-processing of the images included two main steps. First, the registration of the TM and CCD data using the GeoCover Orthorectified Landsat Thematic Mapper Mosaics, that are delivered in a Universal Transverse Mercator (UTM) / World Geodetic System 1984 (WGS84) projection obtained from NASA(2007). Second, the MODIS data in the hierarchical data format (HDF) and sinusoidal projection were transformed to geographic tagged image file format (GeoTIFF) and to UTM/WGS84 projection using the MODIS Reprojection Tool (NASA, 2005). Subsequently, a data bank was built using the SPRING software, a free geographic information system (GIS) and remote sensing image processing system developed by Instituto Nacional de Pesquisas Espaciais (INPE) (Câmara et al., 1996). At this point, an important consideration is that the MODIS geolocation error is of approximately $50 \mathrm{~m}$ $(1 \sigma)$ at nadir (Wolfe et al., 2002), and the Landsat used data geolocation error is less than $250 \mathrm{~m}(1 \sigma)$ and 
comparable to the MODIS error in areas of flat relief when post-processing of satellite ephemeris is used (Lee et al., 2004). The Landsat/TM acquisitions were first compared visually at each site to ensure that they were co-registered correctly in the UTM coordinate system, and when a misregister was verified in both the $\mathrm{X}$ and $\mathrm{Y}$ axes, that acquisition was adequately translated. This way, the Landsat acquisitions at each case were judged to be co-registered within one 30-m TM pixel. This procedure was the same used by Roy et al. (2008), with Landsat Enhanced Thematic Mapper Plus (ETM+) and MODIS/Terra multi-temporal data.

The present work used images from the MODIS sensor, tile H12V10, product MOD13Q1, taking into account seven dates from periods considered ideal for differentiation of crops, from October to March (late spring and summer in the southern hemisphere), as recommended by Van Niel \& McVicar (2004). The chosen dates were 10/16/2005, 11/1/2005, 12/3/2005, $12 / 19 / 2005,1 / 17 / 2006,2 / 18 / 2006$ and $3 / 6 / 2006$. These dates indicate the beginning of each 16-day MOD13Q1 composite image used. The spectral bands used were the red (band 1, centered at $645 \mathrm{~nm}$ ), the near-infrared (band 2, centered at $858.5 \mathrm{~nm}$ ), the medium-infrared (band 6, centered at 1,640 $\mathrm{nm}$ ) and the enhanced vegetation index (EVI) (Justice et al., 2002), which are better to differentiate the soybean areas from the other types of targets of the scene (Rudorff et al., 2007).

The fieldwork was carried out from January 22 to 30, 2006. The collected checkpoints supported the selection of a set of $30 \times 30-\mathrm{km}$ segments, which were used to evaluate the methods of identification and quantification of the area with the soybean crop in the Mato Grosso state. Two routes were established for the collection of checkpoints. The first route explored the agricultural areas of the municipalities of Nova Mutum, Lucas do Rio Verde, Sorriso, Tapurah, Sapezal, Campo Novo do Parecis and Diamantino, located in the central and western regions of the state. The second route went through the agricultural areas of the municipalities of Campo Verde, Primavera do Leste, Santo Antonio do Leste, Novo São Joaquim, Canarana, Querência and Paranatinga, located in the southern and eastern regions of the state. In the fieldwork, 2,076 checkpoints were collected spatially distributed along the main agricultural areas in Mato Grosso state. The acquisition of these points occurred along the main roads, with the aid of a global positioning system (GPS) unit attached to a notebook with Global Mapper 7.0 installed. At each point, five classes of land use/cover were recorded: Cerrado, Forest, Pasture, Soybean and Bare Soil.

The spectral-temporal response surface (STRS) of each pixel was created using a polynomial function parameterized for the 28 control points (MODIS 7 dates and 4 bands), using the "collocation" interpolation method (Watson, 1992; Vieira et al., 2002), which allows an accurate representation of the surface adherence to the control points (Rudorff et al., 2007). All procedures of fitting surfaces were done using an executable algorithm developed by Vieira (2000).

The interpolation of the spectral-temporal variation of different targets results in surfaces with coefficients of varying magnitudes. Then, coefficients were arranged in a scale from 0 to 1 in relation to their minimum and maximum values respectively. The classification was carried out using the maximum likelihood algorithm (MLA) adapted to the STRS method (Vieira, 2000). The MLA performs a supervised classification, and needs a priori knowledge of the number of land use or land cover classes in the scene. Therefore, the land use/ cover information collected along the fieldwork was used to provide the training samples to the classifier. According to the predominant land use/cover verified in the fieldwork, five thematic classes were attributed: Soybean, Forest, Cerrado, Pasture and Bare Soil. To support the supervised classification, pixels representing each of the land cover classes predefined during the fieldwork were selected. For each training pixel, an analytical surface was generated and a training surface feature was then created for each thematic class. In this study, 200 training surfaces were used for each class. After the training process, an analytical surface was created for each pixel of the image, producing a polynomial function for each pixel. The classification of the pixel is made by comparing the coefficients of its function with the coefficients of the polynomial functions of the training surfaces and attributing to the pixel the class with the most similar coefficients.

In order to produce a reference map to evaluate the results generated by the MODIS images classification using the STRS method, a set of 30x30-km segments were classified along the main agricultural regions of Mato Grosso. These segments were chosen and delineated based on fieldwork data, TM/Landsat-5 and CCD/CBERS-2 sensor images. In each segment, the soybean acreage in the summer season of 2005/2006 
was mapped using supervised classification supported by the fieldwork.

As the operational procedure of the STRS classification method is time and computer consuming, its application over the entire area of the MODIS tile H12V10 was considered impracticable. Thus, to test the method, an area with high concentration of soybean and covered by cloud-free Landsat scenes was selected. In this test area $\left(13^{\circ} 40^{\prime} \mathrm{S}\right.$ to $14^{\circ} 50^{\prime} \mathrm{S}$ and $56^{\circ} 00^{\prime} \mathrm{W}$ to $57^{\circ} 50^{\prime} \mathrm{W}$ ), four reference segments of $30 \times 30 \mathrm{~km}$, all belonging to the WRS 227/70 scene of TM/Landsat-5, were completely contained with 343 checkpoints inside. At the end of the STRS classification, a thematic map was obtained for this test area, and its accuracy was evaluated by a confusion matrix and by the Kappa index analysis (Congalton \& Green, 1999).

\section{Results and Discussion}

The surface of each land cover class showed distinct behaviors (Figure 1). However, a slightly similar behavior is observed between Cerrado (Figure $1 \mathrm{~A}$ ), Forest (Figure $1 \mathrm{~B}$ ) and Pasture (Figure $1 \mathrm{C}$ ). Bare Soil presents a distinct surface because the classes with vegetation show higher reflectance values in the near-infrared wavelength (Figure $1 \mathrm{E}$ ). The temporal spectral profile of the soybean show slow reflectance values in the infrared band from October to December (Figure $1 \mathrm{D}$ ), in the beginning of the phenological cycle, since the bare soil response is predominant due to the low soil cover. This behavior changes from December onward, with the vegetative growth of the soybean increasing the soil cover. In the period of maximum vegetative development, the soybean areas showed the highest reflectance values in the infrared wavelength and the minimum values in the red wavelength, due to the leaves' structure and to the high chlorophyll absorption, respectively. However, with the senescence of the cultures (end of February), a decrease in the infrared reflectance and an increase in the red reflectance is noticed. These descriptions agree with several works that analyzed the spectral-temporal behavior of the soybean (Batista et al., 1989; Antunes, 1999; Ferri, 2002; Luiz, 2003).

The soybean EVI temporal profile showed a distinct behavior when compared with the other land cover classes considered (Figure 2). With the use of this vegetation index in the STRS method, the discrimination of the thematic classes became much more efficient in comparison with individual MODIS infrared or red bands. Although a certain similarity is noted in the Forest and Pasture EVI temporal profile, the pasture sometimes showed lower EVI values, especially in November $1^{\text {st }}$ and December $3^{\text {rd }}$, probably due to soil exposure or to the drier vegetation in that period. At other times, EVI was slightly greater in pasture samples than in forest ones (Figure 2). Albeit unexpected, these results were also found by Huete et al. (2006), and are related with forest phenology, climatic conditions and pasture management. For the Bare Soil class, EVI was kept constantly low along the summer season, because of the absence of vegetation cover.

The MODIS sensor's (MOD13Q1 product) 16-day composite image acquired in January 17, 2006 is showed in Figure $3 \mathrm{~A}$, while Figure $3 \mathrm{~B}$ presents the final results of the soybean areas' classification using the STRS method. The first evaluation of the classification was made by the confusion matrix derived from crossing the 343 checkpoints collected in the field and the resulting STRS map. The overall accuracy of the soybean crop areas classification using the STRS method was $80 \%$, with $94 \%$ of "producer accuracy" and $83 \%$ of "user accuracy" (Table 1). However, the method showed an overestimation tendency in soybean acreage, since from 73 non-soybean checkpoints 53 were in fact identified as soybean, what took the producer accuracy to only $27 \%$ for the non-soybean class. This tendency can also be observed in the user accuracy of the non-soybean class, in which, from 36 points classified as non-soybean, 20 points were correct, resulting in a user accuracy of $56 \%$. The Kappa statistic value was 0.26 , which indicates a low level of agreement with the checkpoints found in the fieldwork. However, this result can be explained by the small number of checkpoints collected to evaluate the non-soybean class (73 from 343) (Table 1).

Another approach performed to evaluate the classification was the crosscheck of the thematic maps obtained by the STRS classifier with four reference segments classified with TM/Landsat and $\mathrm{CCD} /$ CBERS-2 data. Among the 30 already mentioned 30x30-km segments, 18 contained field checkpoints. From these 18 segments, four were chosen for the test because they belonged to the same TM/Landsat- 5 scene and were entirely contained in the test area classified by the STRS method (Figure 3). The results of this process, shown in Table 2, especially 

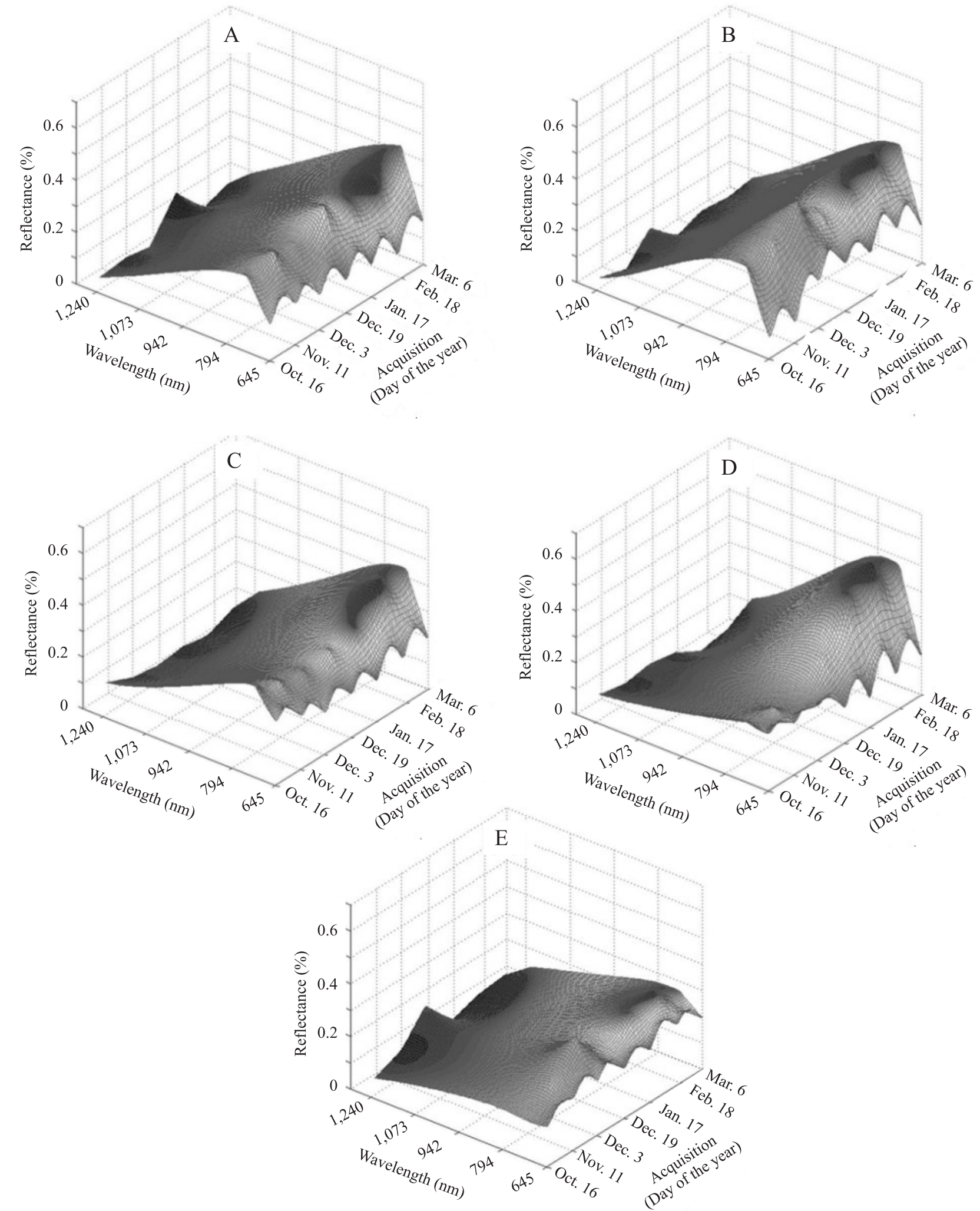

Figure 1. Spectral-temporal response surface (STRS) graphs, plotted using the estimation produced by the executable procedure to fit STRS and manipulated in Matlab, of training pixels for the land cover classes: Cerrado (A); Forest (B); Pasture (C); Soybean (D); Bare Soil (E). 
in segments 3 and 4, confirmed the overestimation of soybean areas by the method. It is also interesting to notice that these two segments, which had the smaller global accuracy values, were the segments with less soybean acreage.

Segments 1 and 2 showed the highest values of global accuracy and user accuracy (Table 2). A high agreement between the STRS classification method and the reference maps for the four segments is noticeable (Figure 4), despite the overestimation of soybean areas. The total area cultivated with soybean in those reference segments was of 124,490 ha, while the STRS thematic

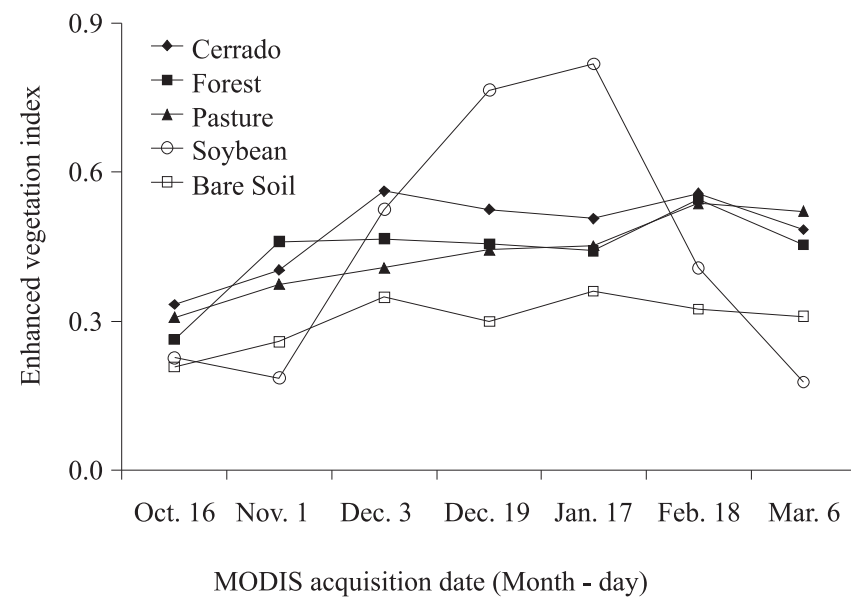

Figure 2. Enhanced vegetation index (EVI) temporal profile for the five mapped land cover classes.

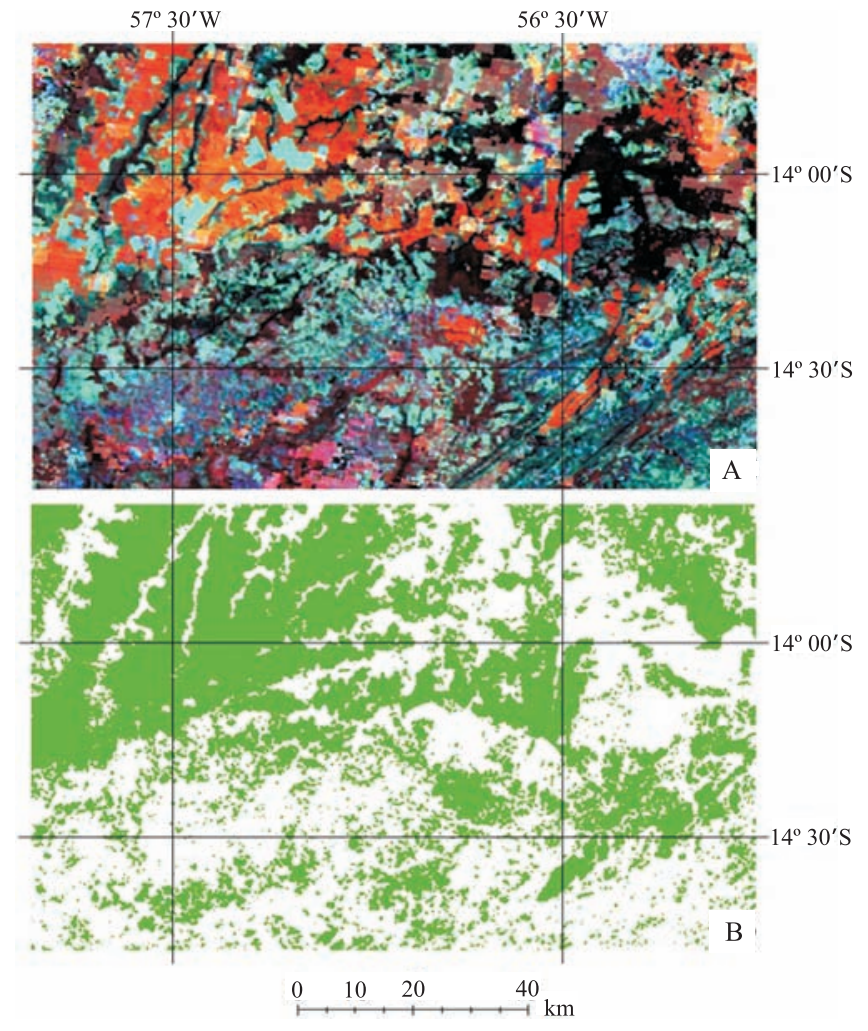

Figure 3. Moderate Resolution Imaging Spectroradiometer (MODIS) colored composition 2R6G1B 16-day composite image of the test area (MOD13Q1 product) from January 17, 2006 (A); thematic map produced by classification using the spectral-temporal response surface (STRS) method over image $3 \mathrm{~A}$, with soybean areas in green and no-soybean areas in white $(B)$.

Table 1. Soybean areas classification using the spectral-temporal response surface (STRS) method. Confusion matrix: STRS $\mathrm{x}$ Field checkpoint data (343 reference data from fieldwork).

\begin{tabular}{|c|c|c|c|c|c|c|c|}
\hline \multirow[t]{2}{*}{ Land cover class } & \multicolumn{2}{|c|}{ Field checkpoint data } & \multirow[t]{2}{*}{ Total } & \multirow{2}{*}{$\begin{array}{c}\text { Commission } \\
\text { error }^{(1)}\end{array}$} & \multirow{2}{*}{$\begin{array}{l}\text { Omission } \\
\text { error }^{(2)}\end{array}$} & \multirow[t]{2}{*}{ User accuracy $^{(3)}$} & \multirow[t]{2}{*}{ Producer accuracy ${ }^{(4)}$} \\
\hline & Soybean & Non-soybean & & & & & \\
\hline & ------- & -(pixel)- & $\begin{array}{ll}----- \\
--\end{array}$ & & 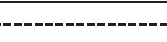 & -(\%)----------- & ------ \\
\hline Soybean & 254 & 53 & 307 & $17(53 / 307)$ & $6(16 / 270)$ & $83(254 / 307)$ & $94(254 / 270)$ \\
\hline Non-soybean & 16 & 20 & 36 & $44(16 / 36)$ & $73(53 / 73)$ & $56(20 / 36)$ & $27(20 / 73)$ \\
\hline Total & 270 & 73 & 343 & & Overall accu & $=(254+20) / 343=$ & $0 \%$ \\
\hline
\end{tabular}

${ }^{(1)}$ Error of inclusion: occurs when an area is included in an incorrect class; ${ }^{(2)}$ Error of exclusion: occurs when an area is excluded from the class to which it belongs; ${ }^{(3)}$ Correct estimation: how much of an area classified as a certain class really belongs to it; ${ }^{(4)}$ Correct classification: how much of an area that really belongs to a certain class was classified in it. Kappa coefficient $=0.26$.

Table 2. Soybean areas classification using the spectral-temporal response surface (STRS) method. Accuracy assessment in four 30x30-km reference segments of TM/Landsat-5 scene (WRS 227/70): STRS x TM/CCD Reference Map.

\begin{tabular}{|c|c|c|c|c|c|}
\hline \multirow{2}{*}{$\begin{array}{l}\text { Reference } \\
\text { segment }\end{array}$} & \multirow{2}{*}{$\begin{array}{c}\text { Overall accuracy } \\
(\%)\end{array}$} & \multicolumn{2}{|c|}{ User accuracy (\%) } & \multicolumn{2}{|c|}{ Producer accuracy (\%) } \\
\hline & & Soybean & Non-soybean & Soybean & Non-soybean \\
\hline 1 & 80 & 74 & 95 & 98 & 57 \\
\hline 2 & 86 & 86 & 85 & 97 & 51 \\
\hline 3 & 74 & 48 & 99 & 98 & 67 \\
\hline 4 & 65 & 34 & 97 & 92 & 58 \\
\hline
\end{tabular}




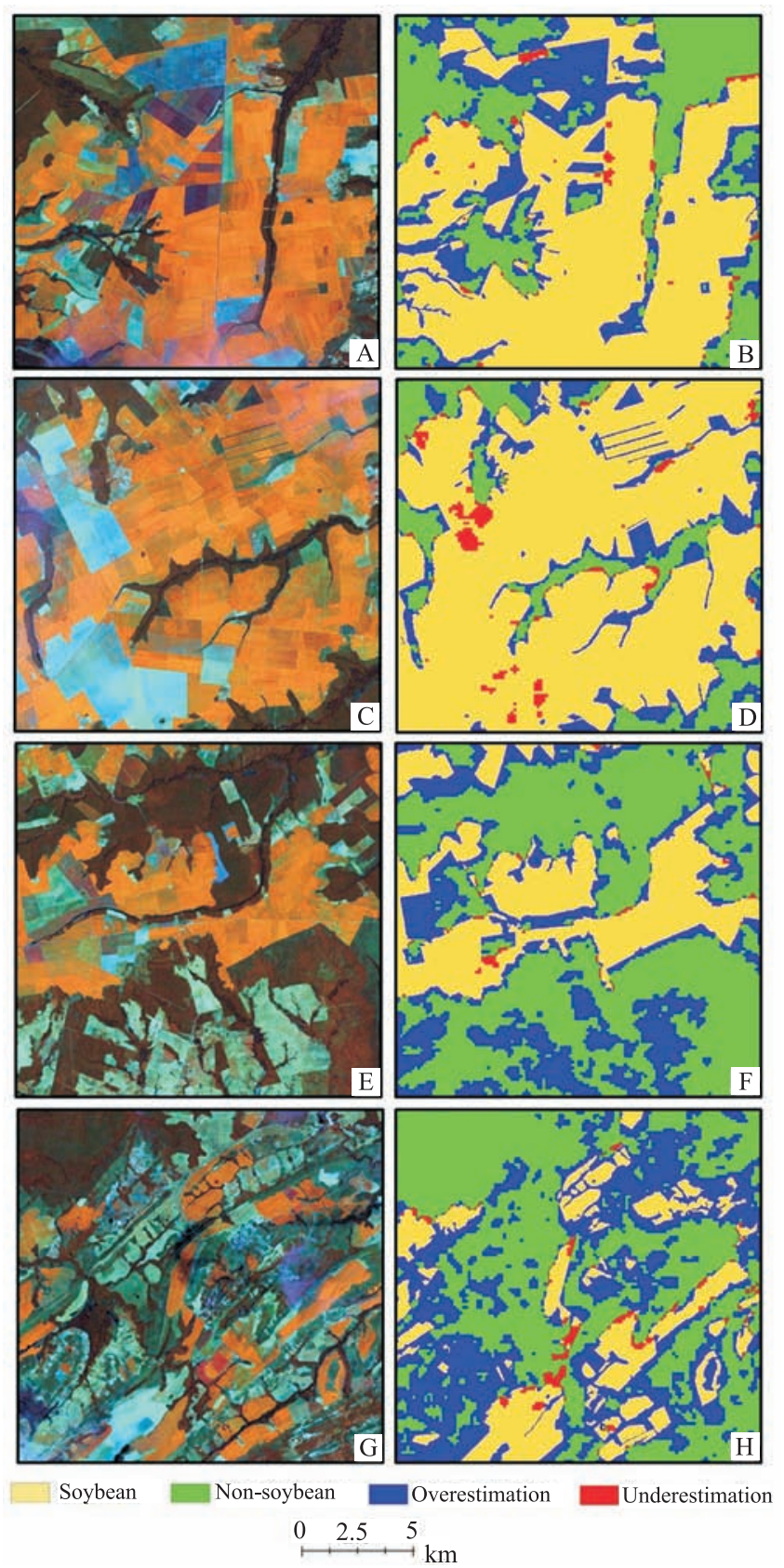

Figure 4. Classification results in four $30 \times 30-\mathrm{km}$ reference segments of the TM/Landsat-5 scene (WRS 227/70). Segments 1 (A and B), 2 (C and D), 3 (E and F) and 4 ( $\mathrm{G}$ and $\mathrm{H})$, where $(\mathrm{A}),(\mathrm{C}),(\mathrm{E})$ and $(\mathrm{G})$ show TM images from January 25, 2006, and (B), (D), (F) and (H) show the spectral-temporal response surface (STRS) classification from Moderate Resolution Imaging Spectroradiometer (MODIS) images.

map resulted in $151,015 \mathrm{ha}$, that is, $21 \%$ more. This fact is attributed to the inclusion, by the classifier, of Forest and Cerrado areas as belonging to the soybean class.
This confusion can be explained by the pixel aggregation effect in spatial resolutions of $250 \mathrm{~m}$, as described by Soares et al. (2008). In fact, these authors, when working with sensors of different spatial resolutions, found that pixels from more fragmented classes, characterized by small polygons, were aggregated by less fragmented classes. Mladinich et al. (2006), in comparison, when working with better resolution images $(30 \mathrm{~m})$ from $\mathrm{TM} /$ Landsat and using an unsupervised clustering approach to map leafy spurge, reached only $63 \%$ in overall classification accuracies.

The results of the classification in segments 3 (Figures $4 \mathrm{E}$ and $\mathrm{F}$ ) and 4 (Figures $4 \mathrm{G}$ and $\mathrm{H}$ ) showed a 40,969-ha soybean area. However, the STRS classification resulted in 95,198 ha, that is, $132 \%$ more. Again, the most confused classes here were the Forest and Cerrado areas. The reasons for this overestimation can be explained by the same arguments provided before for segments 1 and 2 .

Thus, it may be said that the classification method based on the STRS from multispectral and multitemporal MODIS sensor images is promising for the classification of soybean areas in regions with predominance of large farms, which concentrate the highest production volumes in Mato Grosso state. However, the results for fragmented areas and smaller farms should be carefully analyzed, since the classifier was less efficient and overestimated soybean areas.

\section{Conclusions}

1. The classification methodology using the spectral-temporal response surface (STRS) presents a relatively promising result when applied in regions with predominant, large and contiguous soybean areas.

2. The soybean acreage is overestimated using the spectral-temporal response surface (STRS) classification method.

3. Moderate Resolution Imaging Spectroradiometer (MODIS) data (250 m, quasi-daily repeatability) are promising for estimating soybean acreage in regions characterized by large and concentrated fields, like the Mato Grosso state's agricultural conditions.

\section{Acknowledgements}

To Fundação de Amparo à Pesquisa do Estado de São Paulo, for grants; and to Conselho Nacional de Desenvolvimento Científico e Tecnológico, for scholarships to the authors. 


\section{References}

ANTUNES, M.A.H. Avaliação dos modelos SUITS e SAIL no estudo da reflectância da soja (Glycine $\max$ (L.) Merril). 1999. 140p. Dissertação (Mestrado) - Instituto Nacional de Pesquisas Espaciais, São José dos Campos.

BADHWAR, G.D.; AUSTIN, W.W.; CARNES, J.G. A semi-automatic technique for multitemporal classification of a given crop within a Landsat scene. Pattern Recognition, v.15, p.217-230, 1982.

BATISTA, G.T.; RUDORFF, B.F.T.; OVIEDO, A.F.P. Resposta espectral da soja e sua relação com parâmetros agronômicos. In: SIMPÓSIO BRASILEIRO DE SENSORIAMENTO REMOTO, 5., 1988, Natal. Anais. São José dos Campos: Instituto Nacional de Pesquisas Espaciais, 1989. p.406-413.

CÂMARA, G.; SOUZA, R.C.M.; FREITAS, U.M.; GARRIDO, J. Spring: integrating remote sensing and gis by object-oriented data modeling. Computers \& Graphics, v.20, p.395-403, 1996.

CASTILLEJO-GONZÁLEZ, I.L.; LÓPEZ-GRANADOS, F.; GARCÍA-FERRER, A.; PEÑA-BARRAGÁN， J.M.; JURADO-EXPÓSITO, M.; SÁNCHEZ DE LA ORDEN, M.; GONZÁLEZ-AUDICANA, M. Object- and pixel-based analysis for mapping crops and their agro-environmental associated measures using QuickBird imagery. Computers and Electronics in Agriculture, v.68, p.207-215, 2009.

CHEN, S.C. Contribuição de dados de satélite no sistema de previsão de safras. São José dos Campos: Instituto Nacional de Pesquisas Espaciais, 1990. 7p.

CONGALTON, R.G.; GREEN, K. Assessing the accuracy of remotely sensed data: principles and practices. Boca Raton: CRC Lewis Press, 1999. 137p.

DORAISWAMY, P.C.; HATFIELD, J.L.; JACKSON, T.J.; AKHMEDOV, B.; PRUEGER, J.; STERN, A. Crop condition and yield simulations using Landsat and MODIS. Remote Sensing of Environment, v.92, p.548-559, 2004.

DRONIN, N.M.; BELLINGER, E.G. Climate dependence and food problems in Russia, 1900-1990: the interaction of climate and agricultural policy and their effect on food problems. Budapest: Central European University Press, 2005. 366p.

EPIPHANIO, J.C.N.; LUIZ, A.J.B.; FORMAGGIO, A.R. Estimativa de áreas agrícolas municipais, utilizando sistema de amostragem simples sobre imagens de satélite. Bragantia, v.61, p.187-197, 2002.

EPIPHANIO, R.D.V. Avaliação da potencialidade das imagens MODIS na estimação da área de soja no Estado do Mato Grosso. 2007. 89p. Dissertação (Mestrado) - Instituto Nacional de Pesquisas Espaciais, São José dos Campos.

FERRI, C.P. Utilização da reflectância espectral para a estimativa de pigmentos fotossintéticos em dosséis de soja [Glycine max (L.), Merril]. 2002. 173p. Tese (Doutorado) - Instituto Nacional de Pesquisas Espaciais, São José dos Campos.

FOOD AND AGRICULTURE ORGANIZATION OF THE UNITED NATIONS. Multiple frame agricultural surveys: agricultural survey programs based on area frame or dual frame (area and list) sample design. Rome: FAO, 1998. v.2, 242p. (FAO. Statistical development series, 10).

HUETE, A.R.; DIDAN, K.; SHIMABUKURO, Y.E.; RATANA, P.; SALESKA, S.R.; HUTYRA, L.R.; YANG, W.; NEMANI, R.R.; MYNENI, R. Amazon rainforests Green-up with sunlight in dry season. Geophysical Research Letters, v.33, 2006. Doi: 10.1029/2005GL025583.

INSTITUTO BRASILEIRO DE GEOGRAFIA E ESTATÍSTICA. Pesquisas agropecuárias. Rio de Janeiro: IBGE, 2002. v.6, 96p. (Série relatórios metodológicos).

IPPOLITI-RAMILO, G.A. Imagens TM/Landsat-5 da época de pré-plantio para a previsão da área de culturas de verão. 1999. 183p. Dissertação (Mestrado) - Instituto Nacional de Pesquisas Espaciais, São José dos Campos.

JUSTICE, C.O.; TOWNSHEND, J.R.G.; VERMOTE, E.F.; MASUOKA, E.; WOLFE, R.E.; SALEOUS, N.; ROY, D.P.; MORISETTE, J.T. An overview of MODIS land data processing and product status. Remote Sensing of Environment, v.83, p.3-15, 2002.

LEE, D.S.; STOREY, J.C.; CHOATE, M.J.; HAYES, R. Four years of Landsat-7 on-orbit geometric calibration and performance. IEEE Transactions on Geoscience and Remote Sensing, v.42, p.2786-2795, 2004.

LUIZ, A.J.B. Estatísticas agrícolas por amostragem auxiliadas pelo sensoriamento remoto. 2003. 112p. Tese (Doutorado) Instituto Nacional de Pesquisas Espaciais, São José dos Campos.

MLADINICH, C.S.; BUSTOS, M.R.; STITT, S.; ROOT, R.; BROWN, K.; ANDERSON, G. L.; HAGER, S. The use of Landsat 7 Enhanced Thematic Mapper plus for mapping leafy spurge. Rangeland Ecology \& Management, v.59, p.500-506, 2006.

NASA. Applied sciences directorate. Available at: $<$ http://zulu. ssc.nasa.gov/mrsid/>. Accessed on: 08 Aug. 2007.

NASA. Land Processes Distributed Active Archive Center. MODIS reprojection tool. Available at: $<$ http://lpdaac.usgs.gov $>$. Accessed on: 02 Sept. 2005.

PINO, F.A. Estatísticas agrícolas para o século XXI. Agricultura em São Paulo, v.46, p.71-105, 1999.

PRASAD, A.K.; CHAI, L.; SINGH, R.P.; KAFATOS, M. Crop yield estimation model for Iowa using remote sensing and surface parameters. International Journal of Applied Earth Observation and Geoinformation, v.8, p.26-33, 2006.

ROY, D.P.; JU, J.; LEWIS, P.; SCHAAF, C.; GAO, F.; HANSEN, M.; LINDQUIST, E. Multi-temporal MODIS-Landsat data fusion for relative radiometric normalization, gap filling, and prediction of Landsat data. Remote Sensing of Environment, v.112, p.3112-3120, 2008.

RUDORFF, C. de M.; RIZZI, R.; RUDORFF, B.F.T.; SUGAWARA, L.M.; VIEIRA, C.A.O. Superfícies de resposta espectro-temporal de imagens do sensor MODIS para classificação de área de soja no Estado do Rio Grande do Sul. Ciência Rural, v.37, p.118-125, 2007.

SANCHES, I.D.A. Sensoriamento remoto para o levantamento espectro-temporal e estimativas de área de culturas agrícolas. 2004. 172p. Dissertação (Mestrado) - Instituto Nacional de Pesquisas Espaciais, São José dos Campos. 
SOARES, D. de M.; GALVÃO, L.S.; FORMAGGIO, A.R. Crop area estimate from original and simulated spatial resolution data and landscape metrics. Scientia Agricola, v.65, p.459-467, 2008.

VAN NIEL, T.G.; MCVICAR, T.R. Determining temporal windows of crop discrimination with remote sensing: a case study in south-eastern Australia. Computers and Electronics in Agriculture, v.45, p.91-108, 2004.

VIEIRA, C.A.O. Accuracy of remotely sensing classification of agricultural crops: a comparative study. 2000. 352p. Thesis (Doctor) - University of Nottingham, Nottingham.
VIEIRA, C.A.O.; MATHER, P.M.; APLIN, P. Multitemporal classification of agricultural crops using the spectral-temporal response surface. In: BRUZZONE, L.; SMITS, P. (Org.). Analysis of multi-temporal remote sensing images. London: World Scientific, 2002. p.290-297.

WATSON, D.F. Contouring: a guide to the analysis and display of spatial data. Oxford: Pergamon Press, 1992. 321p.

WOLFE, R.E.; NISHIHAMA, M.; FLEIG, A.J.; KUYPER, J.A.; ROY, D.P.; STOREY, J.C.; PATT, F.S. Achieving sub-pixel geolocation accuracy in support of MODIS land science. Remote Sensing of Environment, v.83, p.31-49, 2002.

Received on August 31, 2009 and accepted on November 24, 2009 